\title{
大和川の生活排水起源物質の 河川内での変化 CHANGES OF SUBSTANCES DERIVED FROM DOMESTIC SEWAGE IN YAMATOGAWA RIVER BASIN
}

\author{
谷口正伸 ${ }^{1} \cdot$ 井伊博行 $^{2} \cdot$ 平田健正 ${ }^{3} \cdot$ 石塚正秀 $^{4}$ \\ Masanobu TANIGUCHI, Hiroyuki II , Tatemasa HIRATA, Masahide ISHIZUKA \\ ${ }^{1}$ 学生会員 和歌山大学大学院 システム工学研究科（T640-8510 和歌山市栄谷 930) \\ ${ }^{2}$ 正会員 博（理） 和歌山大学教授 システム工学部（テ640-8510 和歌山市栄谷 930) \\ ${ }^{3}$ 正会員 工博 和歌山大学教授 システム工学部（テ640-8510 和歌山市栄谷 930） \\ ${ }^{4}$ 正会員 博（工） 和歌山大学助手 システム工学部（テ640-8510 和歌山市栄谷 930）
}

\begin{abstract}
Seasonal Concentrations of BOD, $\mathrm{NH}_{4}{ }^{+}-\mathrm{N}$ and interfacial active agent derived from domestic sewage were high in winter and low in summer. The concentrations decreased with an increase in water temperature. Generally, river water contains organic compounds and $\mathrm{Cl}^{-}$derived from domestic sewage and $\mathrm{Cl}^{-}$was quite stable in rivers. As the ratios of $\mathrm{BOD} / \mathrm{Cl}^{-}$and $\mathrm{NH}_{4}{ }^{+}-\mathrm{N} / \mathrm{Cl}^{-}$decreased down the stream and changed seasonally, organic compounds were thought to be decomposed during flow. $\mathrm{NO}_{3}^{-}-\mathrm{N} / \mathrm{Cl}^{-}$which organic compounds were finally decomposed into, also decreased down the stream and were high in winter and low in summer. $\mathrm{NO}_{3}^{-}-\mathrm{N}$ was thought to be used for photosynthesis because $\mathrm{pH}$, DO values and chlorophyll concentration of the Yamato river increased with temperature and decrease of $\mathrm{NO}_{3}-\mathrm{N}$ concentration.
\end{abstract}

Key Words: $\mathrm{BOD}, \mathrm{NH}_{4}{ }^{+}-\mathrm{N}$, nitrogen, water pollution, photosynthesis

\section{1. はじめに}

大和川は近年急激な都市化に伴い，水質污濁が原因と なっている河川である. その背景として, 高度成長期に 上流，中流域が格好のニュータウンとして注目され，人 ロが急増した. そのため行政の社会基盤の整備が都市化 の速度に追いつかず，下水処理施設の不整備などから生 活雑排水が河川に流れ込み，水質污濁が進んだためであ る ${ }^{1)}$. このように自浄能力を超えた污濁により，大和川 では水質悪化が問題となってきている. そこで, 水質改 善運動として, 大和川クリーンキャンペーンが 1985 年か ら始まり 2002 年まで実施され，様々な生物が生息でき， 人々に親しまれ，景観の保全が図られるような良好な水 環境へ改善しようと,さまざまなイベントが実施された。 また, 1994 年 11 月に, 水環境改善緊急行動計画として 大和川清流ルネッサンス 21 が策定された ${ }^{1)}$. その計画で は水質目標を定め, この目標を達成するために, 河川の
浄化，下水道整備，家庭での生活排水対策など，水環境 にかかわる総合的な施策が実施された。 しかしながら， 近年浄化施設や下水処理施設が数々設置され，これらの イベント活動や地域の活動により水質は徐々に改善され てはいるもののその効果はあまりあがっておらず，依然 として環境基準值を満たしていないのが現状である。 そ のため，大和川支流の石川において，土地利用と水質の 関係や 1999 年, 2000 年の現地調査のデータを用いた河 川水の水質特性について研究がなされてきた ${ }^{2), 3)}$. また, 石川と大和川本流での定点長期データを用いて，BOD, ア ンモニア態窒素, 陰イオン界面活性剂について, 生活排 水に原因があり, 濃度の水温依存性により冬に水質が悪 化することを解明したが，詳しい水質変化の現象までは 解明されていなかった ${ }^{4}$.

そこで，本研究では過去の長期データと広域での現地 調査のデータにより, 水質が改善しない原因を解明し, 水質の傾向と河川での物質の動向を把握し, 水質変化の 原因について解析を行う。 その中で, 生活排水や産業排 


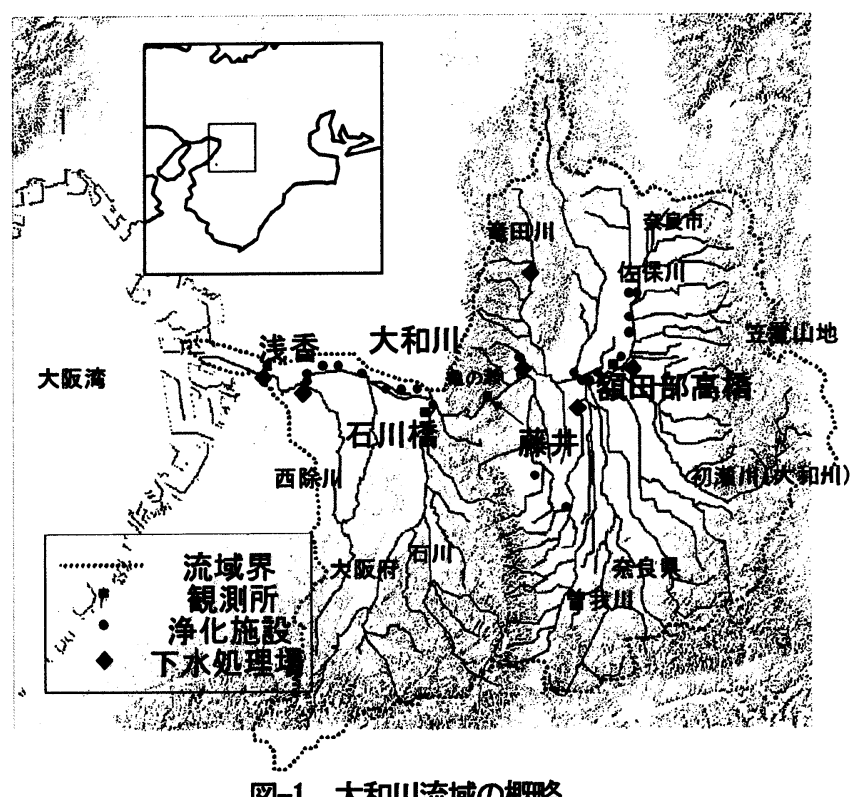

図-1 大和川流域の概略

水に主に含まれる窒素に着目し、BOD，アンモニア態窒素 や硝酸態窒素濃度, 陰イオン界面活性剂についての考察 を行った. また, この水質データを統計的に処理し, 相 互の物質濃度の関係や濃度と水温, 流量との関係につい て考察を行った.

\section{2. 研究対象地の概要}

大和川は奈良県と大阪府南部を流れる全長 $68 \mathrm{~km} の 1$ 級河川である. 大和川は笠置山地から始まり，佐保川， 兽我川, 竜田川などの奈良盆地の水を集め, 奈良県と大 阪府の境にある亀の瀬の渓谷部を経て, 大阪平野に入る. 奈良盆地を囲む山地や奈良盆地の地盤は火成岩からなり， 奈良盆地の水は全て亀の瀬に集まる. この後, 石川や西 除川等を合わせ，大阪湾に注いでいる．流域面積は $1070 \mathrm{~km}^{2}$ であり, 奈良県, 大阪府の 41 市町村に約 200 万 人もの人が生活している. また, 2000 年度の下水処理普 及率は大阪府で $55.0 \%$, 奈良県では $57.8 \%$ と低くなってい る. また, 2000 年度の全国 1 級河川の BOD75\%値において ワースト1位を記録している ${ }^{5)}$.

\section{3. 研究方法}

研究を行うにあたり，国土交通省の 1983 年から 1999 年 の水質及び流量データと和歌山大学が 2000 年に行った 現地調查のデータを用いて解析を行った. 考察に用いた 項目は流量, 水温, $\mathrm{pH}, \mathrm{DO}, \mathrm{BOD}$, アンモニア態窒素, 硝 酸態窒素濃度である ${ }^{6}$. 観測所の位置を図-1 に示す．大 和川には主な観測所として, 下流から, 浅香, 河内橋, 石川橋, 国豊橋, 藤井, 額田部高橋があり,ここでは代 表としてデータ数が最も多い藤井」のデータを用いた.

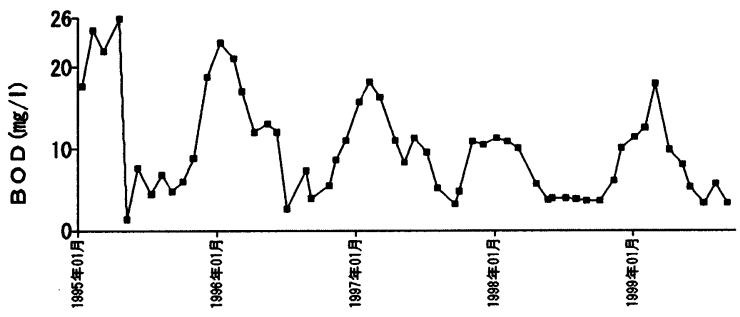

図-2 藤井におけるBODの経年変化

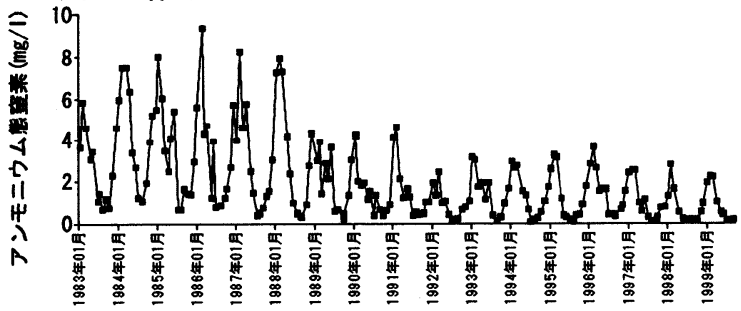

図-3＼cjkstart藤井におけるアンモニア態窒素濃度の経年変化

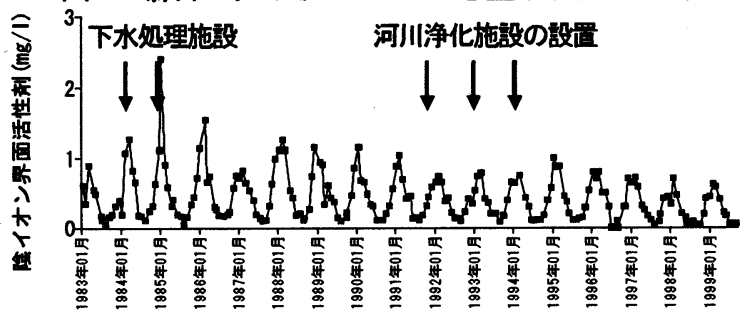

図-4藤井における陰イオン界面活性剂濃度の経年変化

観測所ではそれぞれ月に 1 回の定期観測が行われている. 流域にある下水処理施設は, 奈良県では 1974 年から, 大 阪府では 1979 年に設置されはじめ, 1985 年前後にも新 たに建設された. また, 河川浄化施設は 1992 年から 1994 年にかけて建設が進められている. この下水処理施設の 建設年度や河川浄化施設の設置年度とともに，水質とあ わせて考察する. 過去の長期データだけでは平面的な変 化を考察できないために, 和歌山大学では 2000 年 1 月と 10 月に大和川全体で 70 地点の調査を害施し，そのデー 夕を解析に用いた. これらの水質, 流量データとともに 河川で起こっている現象を推察した。

\section{4. 水質变化の傾向と浄化施設の関連性}

藤井は大和川本流の奈良県内の最下流部にある. 図-2 から図-4 に，BOD，アンモニア態窒素濃度，陰イオン界 面活性剤濃度の経年変化をそれぞれ示す，流域中での現 象を解明するために，それぞれの水質項目の変化パター ンについて考察した. 1 年での変化を見ると, BOD, アン モニア態窒素濃度, 陰イオン界面活性剂濃度は規則的な 変化が明確に見られ, 2 月をピークに, 冬に濃度が高く, 夏に低くなる傾向がある. この変化が浄化施設の影響で あるかどうかを確認するために，図-4 の矢印で浄化施設 の設置年度を示した. 浄化施設の設置年と水質の変化を 比較すると浄化施設の設置年には水質に大きな変化が見 られない。このため, 濃度変化は净化施設の設置年に影 


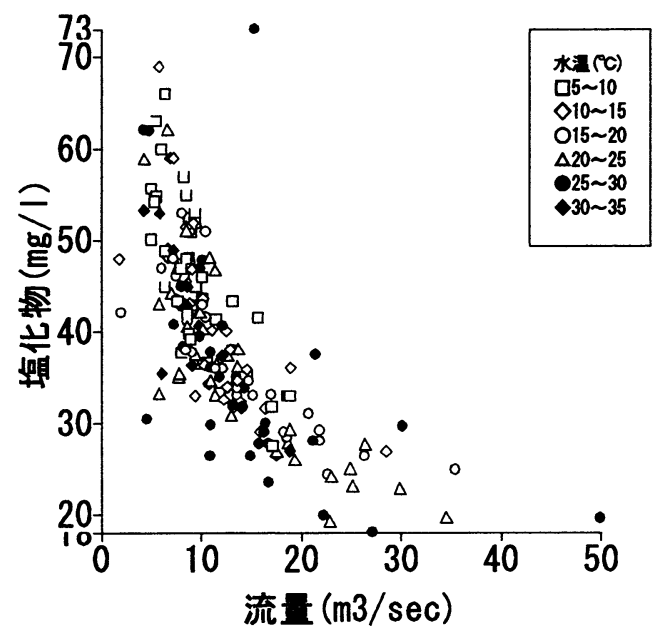

図-5 水量每の熄化物イオン標度と流是との関系

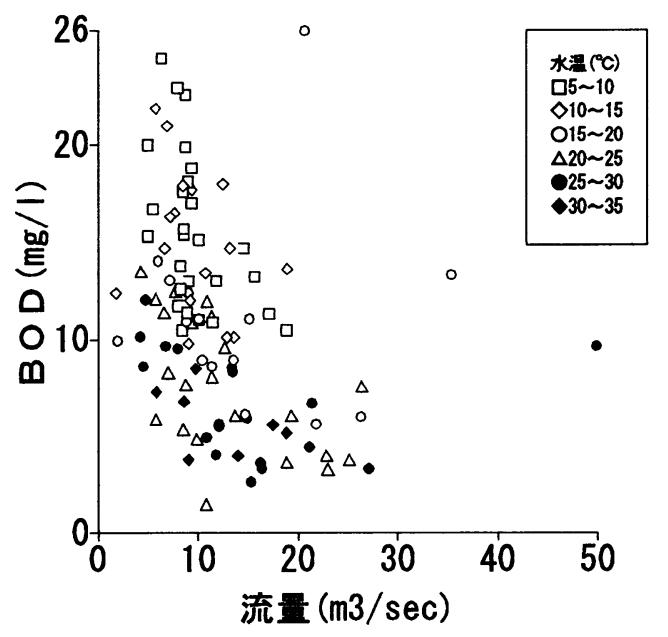

図6 水昷每のBD と流量との関系

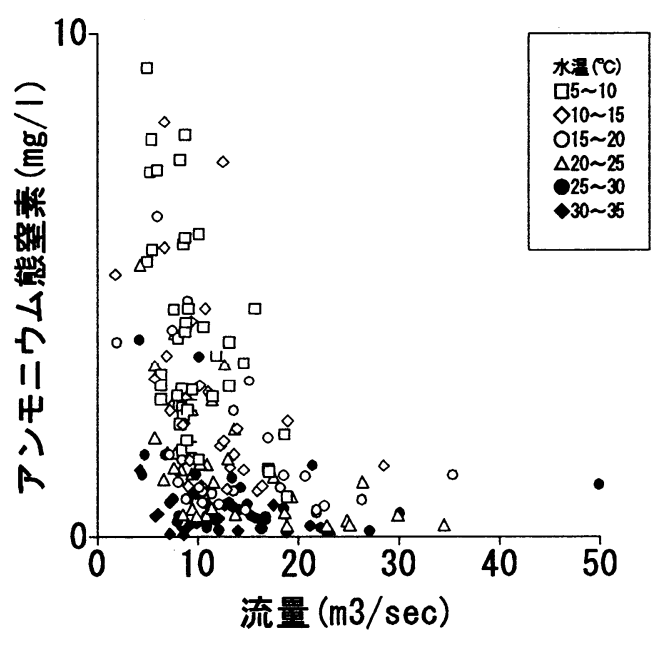

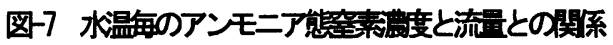

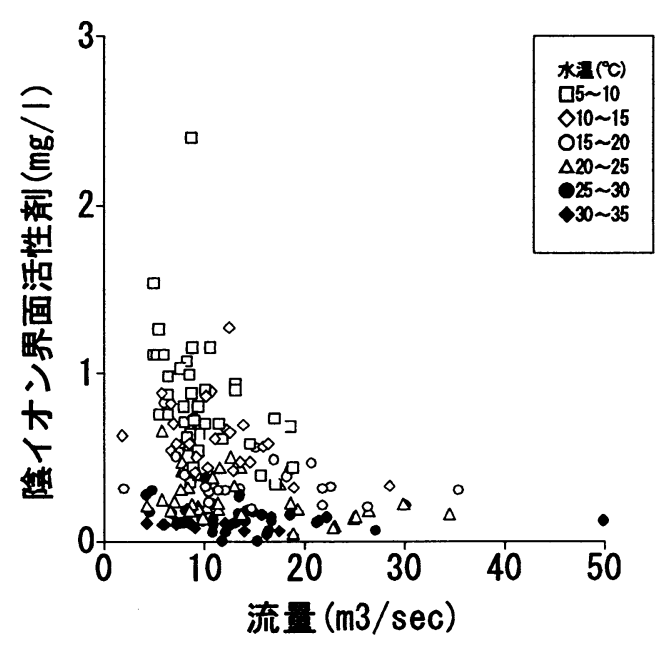

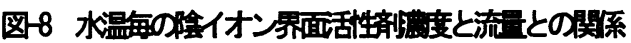

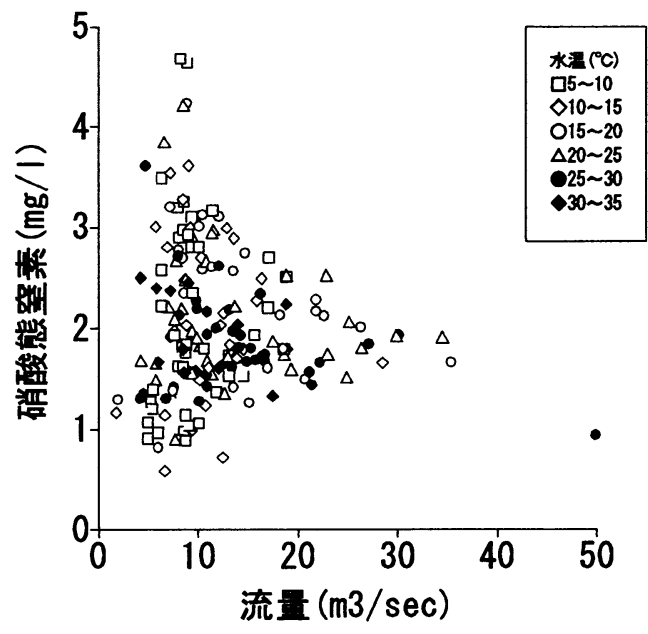

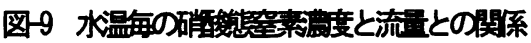

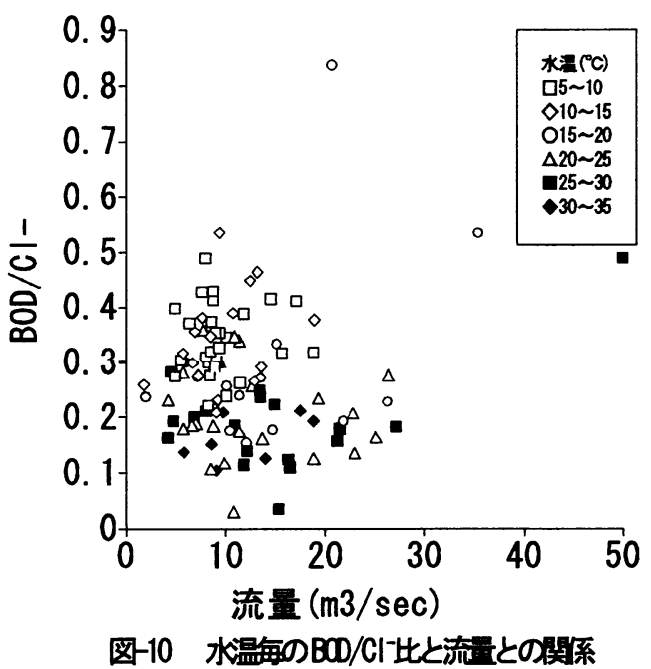

图-10 水昷每のBO/Cl-比之流贵との関系
響しておらず, 浄化施設の影響とは考えにくい. BOD，陰 イオン界面活性剤はそれぞれ有機物量の指標であり，陰 イオン界面活性剂は生活排水のみに起因する物質で生活 排水を考察するのに重要な指標となる. また, アンモニ アは有機物が分解されるときに生成され，酸素が存在す ると酸化されて, 硝酸イオンになる. このことから, 濃 度変化の原因の 1 つとして, 有機物の分解が考えられる.

\section{5. 濃度と流量及ひ水温との関係}

BOD, アンモニア態窒素, 陰イオン界面活性剂濃度の変 化は先行降雨の状態による希釈の影響あるいは光合成や 分解などの影響が考えられ, 流量及び水温により濃度が 


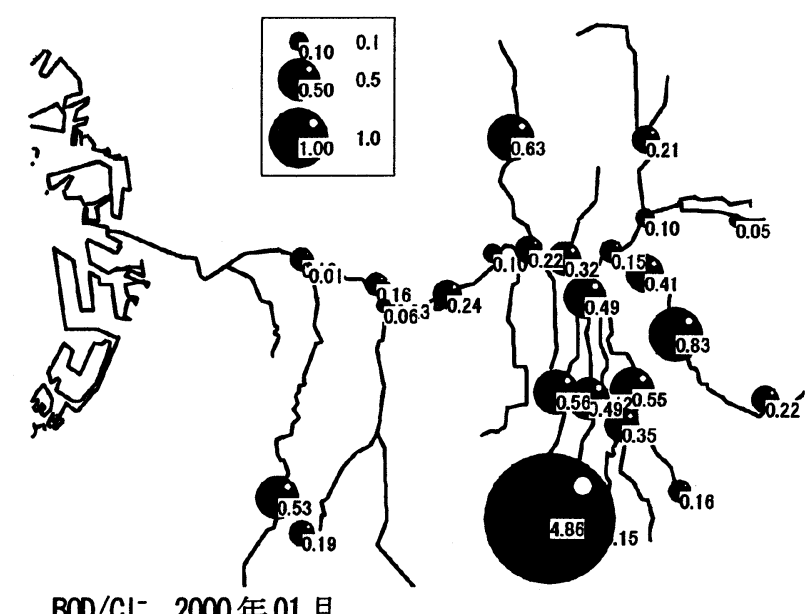

$\mathrm{BOO} / \mathrm{Cl}^{-} 2000$ 年01月

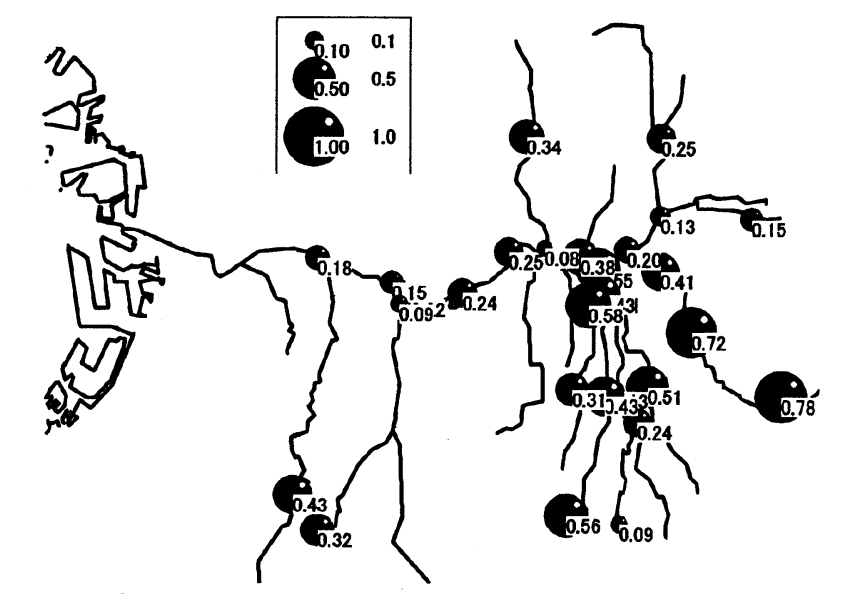

$\mathrm{BOD} / \mathrm{Cl}^{-} 2000$ 年 10 月

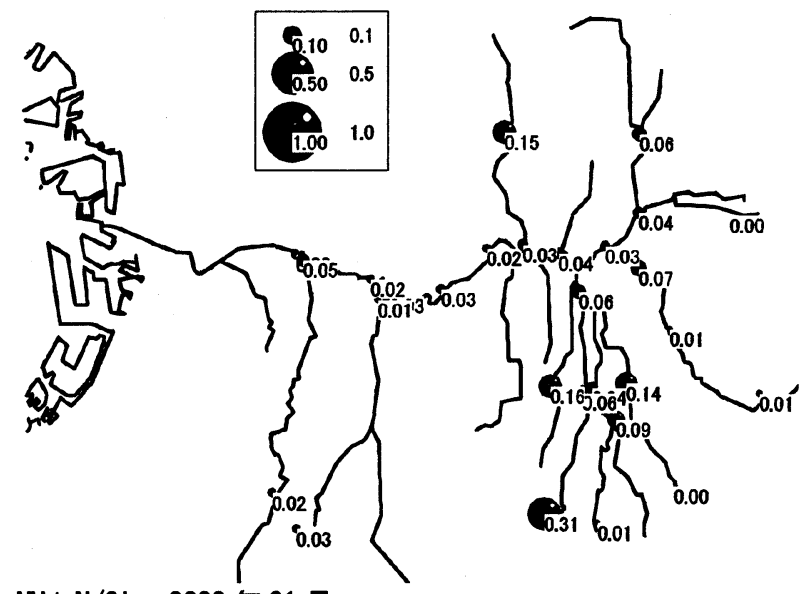

$\mathrm{NH}_{4}^{+}-\mathrm{N} / \mathrm{Cl}^{-} 2000$ 年 01 月

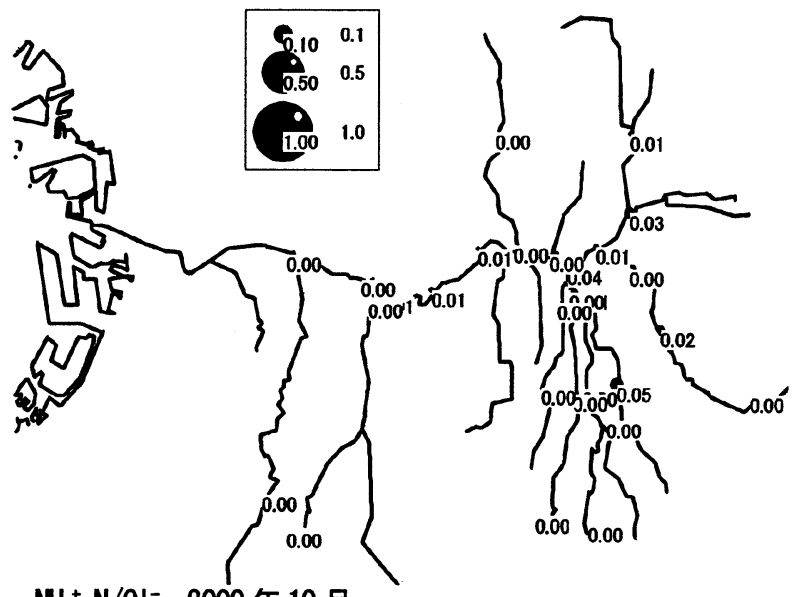

$\mathrm{NH}_{4}{ }^{+}-\mathrm{N} / \mathrm{Cl}^{-} 2000$ 年 10 月

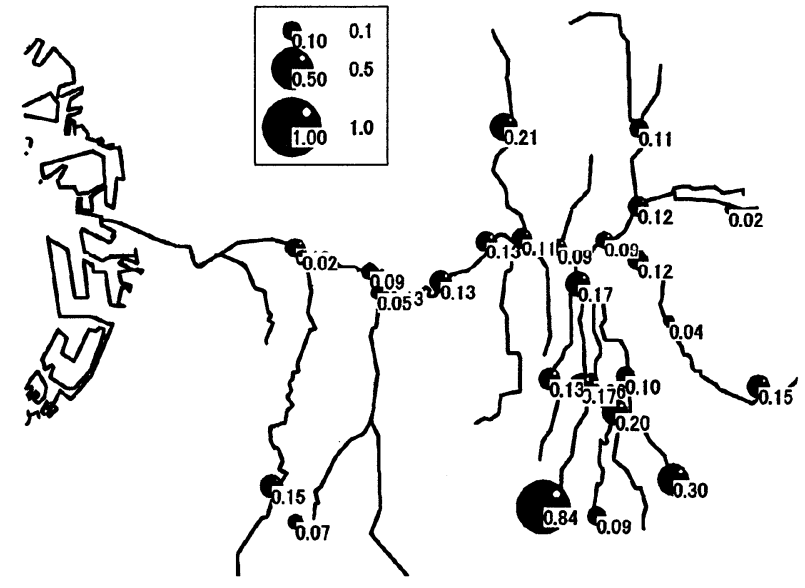

$\mathrm{NO}_{3}^{-}-\mathrm{N} / \mathrm{Cl}^{-} 2000$ 年 01 月

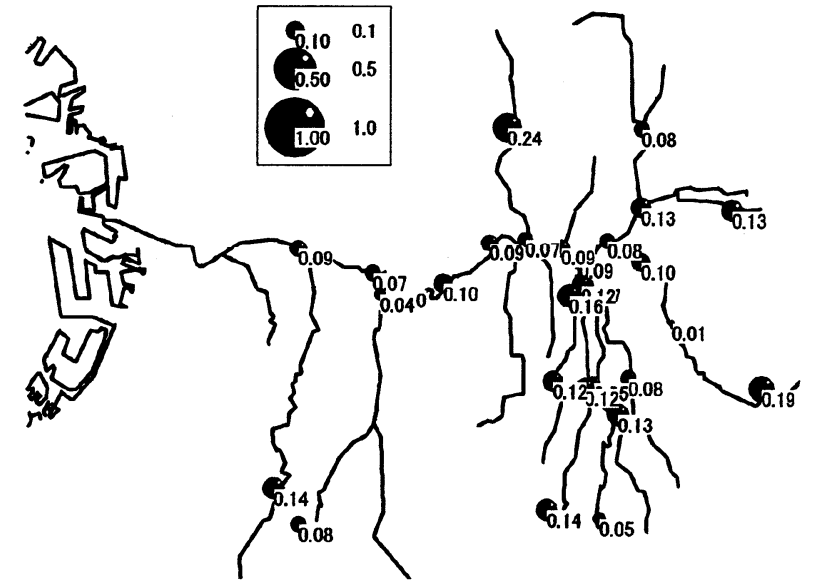

$\mathrm{NO}_{3}^{-}-\mathrm{N} / \mathrm{Cl}^{-} 2000$ 年 10 月

図-11 $\mathrm{BOO} / \mathrm{Cl}^{-}, \mathrm{NH}_{4}^{+}-\mathrm{N} / \mathrm{Cl}^{-}, \mathrm{NO}_{3}^{-}-\mathrm{N} / \mathrm{Cl}^{-}$比の平面分布

変化すると考えられる. 図-5 に塩素イオン濃度, 図-6 にBOD，図-7にアンモニア態窒素濃度, 図-8に陰イオン 界面活性剂濃度, 図-9に硝酸態窒素濃度の水温毎の流量 との関係をそれぞれ示す. 図中に水温が $25^{\circ} \mathrm{C}$ より高いと きの濃度をぬりつぶしのマークで示寸. 図-5 塩素イオ ン濃度は流量が増加すると減少する傾向がみられ，水温 が変化しても, 濃度と流量の関係には変化がみられない。 塩素イオンも生活排水に起因すると考えられ，濃度が流
量に依存することから，降雨などにより河川流量が増加 すること（希釈効果）により，濃度が変動すると考えら れる. しかし，図-6から図-8のBOD，アンモニア態窒素 濃度, 陰イオン界面活性剂と流量との関係は水温が高い ほど濃度が低い傾向を示す。このことから，BOD，アンモ 二ア態窒素濃度, 陰イオン界面活性剂濃度は水温に大き く依存していることが判る. 一方, 図-9 の硝酸態窒素濃 度は，BOD やアンモニア態窒素濃度とは違った傾向が見 


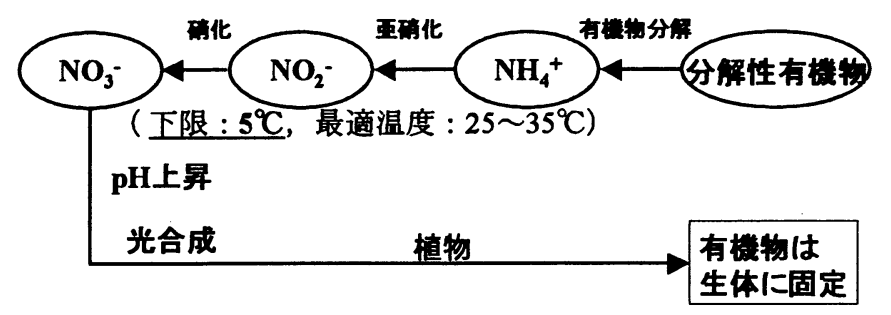

図-12 流域での反応概略図

られ，水温が低い場合に濃度がばらつき，水温が高くな ると一定の濃度に分布が集中する. このことから，硝酸 態窒素濃度も水温の影響があると考えられるが，一方的 に水温が高くなると硝酸態窒素濃度が高くならないこと がわかる.

\section{6. 河川中での分解の影響について}

ここで, 塩素イオン，BOD はともに生活排水を起源と する物質である. BOD は分解するが，塩素イオンは河川 中では分解しない7)，8)。このとから，両者の比を取る ことで，流量に関倸なく，生活排水の影響を見ることが できる. 図-10に藤井におおける水昷每の BOD/Cl一比と流量の関 係を示す. $\mathrm{BOD} / \mathrm{Cl}^{-}$比は流量と関係が見られず，水温が上 昇すると $\mathrm{BOD} / \mathrm{Cl}^{-}$比は减少することから, $\mathrm{BOD}$ の季節変化 は生活排水が冬に選択的に多いのが原因ではなく, 気温 の高い時期に有機物が選択的に分解することで，夏に有 機物の濃度が減少していることがわかる.

次に, 流下過程での変化をみるために, 2000 年 1 月, 10 月の現地調査データを用いて, $\mathrm{BOD} / \mathrm{Cl}^{-}$比, $\mathrm{NH}_{4}{ }^{+}-\mathrm{N} / \mathrm{Cl}^{-}$ 比, $\mathrm{NO}_{3}^{-}-\mathrm{N} / \mathrm{Cl}^{-}$比の平面分布を示し, 河川での分解の状況 を考察する. 図-11 の上段に 2000 年 1 月と 2000 年 10 月 の $\mathrm{BOD} / \mathrm{Cl}^{-}$比を, 中段に 1 月と 10 月の $\mathrm{NH}_{4}^{+}-\mathrm{N} / \mathrm{Cl}^{-}$比を, 下段に 1 月と 10 月の $\mathrm{NO}_{3}^{-}-\mathrm{N} / \mathrm{Cl}^{-}$比の平面分布を示寸. $\mathrm{BOD} / \mathrm{Cl}^{-}$比は 10 月よりも 1 月の方が全体的に高い傾向を 示す. 一部の最上流部 (例えば, 東部の支流) では生活 排水の混入がないため, BOD/Cl-比は低い傾向が見られる が，生活排水が混入する中流では $\mathrm{BOD} / \mathrm{Cl}^{-}$比が上昇し, 本流の $\mathrm{BOD} / \mathrm{Cl}^{-}$比は減少している.このことから，有機 物は生活排水から流域に供給され，その生活排水の BOD/C1'比が下流ほど低くなることは考えられないので, 流下過程で, 有機物が分解していることが考えられる. 同様に，有機物から硝酸イオンの中間生成物であるアン モニアイオンの $\mathrm{NH}_{4}{ }^{+}-\mathrm{N} / \mathrm{Cl}^{-}$比も， 1 月で高く, 10 月は多 くの地点で $0.0 \mathrm{mg} / 1$ と低く, 下流ほど低くなっている. これも，夏に有機物が選択的に河川内で分解し，下流ほ ど低くなったと解积される. 次に, 分解過程での最終生 成物である硝酸イオンの $\mathrm{NO}_{3}^{-}-\mathrm{N} / \mathrm{Cl}^{-}$比も， 1 月の方が 10 月よりも高く, 流下寸るにつれて減少している. 有機物 の分解によって, 最終的に硝酸イオンになるので, $\mathrm{BOD} / \mathrm{Cl}^{-}$比, $\mathrm{NH}_{4}^{+}-\mathrm{N} / \mathrm{Cl}^{-}$比が減少すれば, $\mathrm{NO}_{3}^{-}-\mathrm{N} / \mathrm{Cl}^{-}$比は增

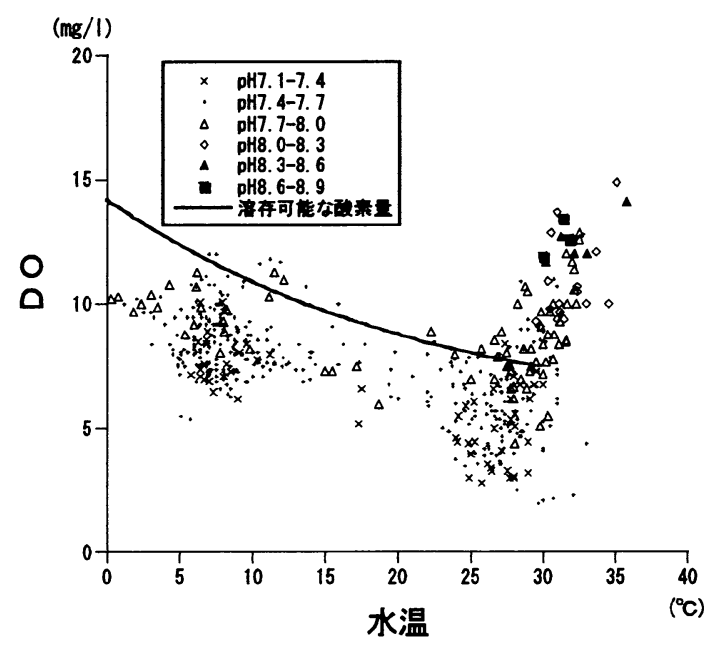

図-13 D0 と水温， pH との関係

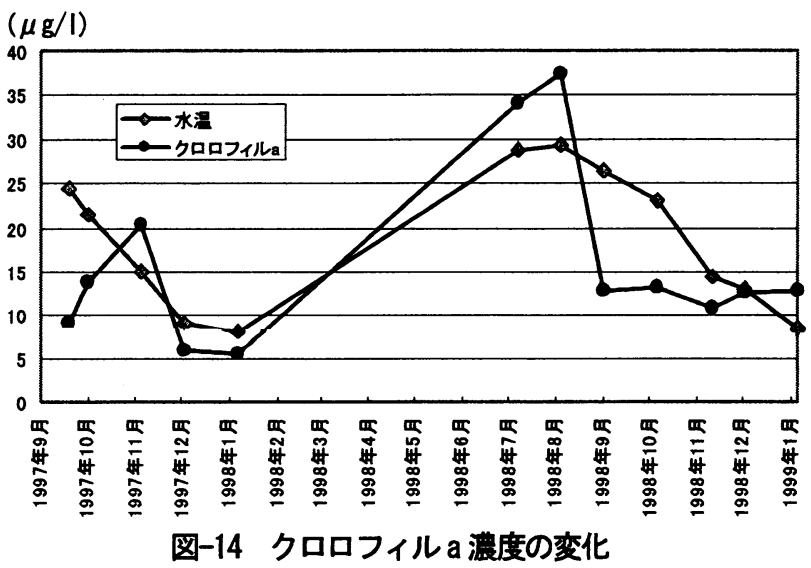

加するはずである. しかしながら, $\mathrm{NH}_{4}^{+}-\mathrm{N} / \mathrm{Cl}^{-}$比も流下す るにつれて減少し, 夏に低くなることから, 分解や脱窒 などの分解以外の反応が河川内で起こっていることが考 えられる.

\section{7. 光合成の影響について}

有機物の分解と同様に，河川内で水温の影響のある硝酸 イオン濃度に影響を与える現象として, 光合成が考えら れる. 図-12 に流域内での反応概略を示す. 光合成の反 忘は式(1)で示されるように硝酸が減少し, 有機物として 植物に固定される. このとき, 反応により水素イオンが 使われるため, $\mathrm{pH}$ は上昇し, 酸素濃度は増加する.

$$
\begin{aligned}
106 \mathrm{CO}_{2} & +6 \mathrm{NO}_{3}^{-}+16 \mathrm{H}^{+}+\mathrm{H}_{3} \mathrm{PO}_{4}+122 \mathrm{H}_{2} \mathrm{O} \\
& \rightarrow \text { 有機物 }+138 \mathrm{O}_{2}
\end{aligned}
$$

このことから, 光合成について解析するため, 図-13 に藤井における DO と水温, $\mathrm{pH}$ との関係を示す. 図中の 実線は 1 気圧 $25^{\circ} \mathrm{C} に お け る$ 飽和溶存酸素量である. 図中 で 7.7 以上の $\mathrm{pH}$ のプロットサイズを大きく示してある. $25^{\circ} \mathrm{C}$ 以下では $\mathrm{pH}$ は 8 以下で, $25^{\circ} \mathrm{C}$ 以上で $\mathrm{pH}$ は 8 以上と 


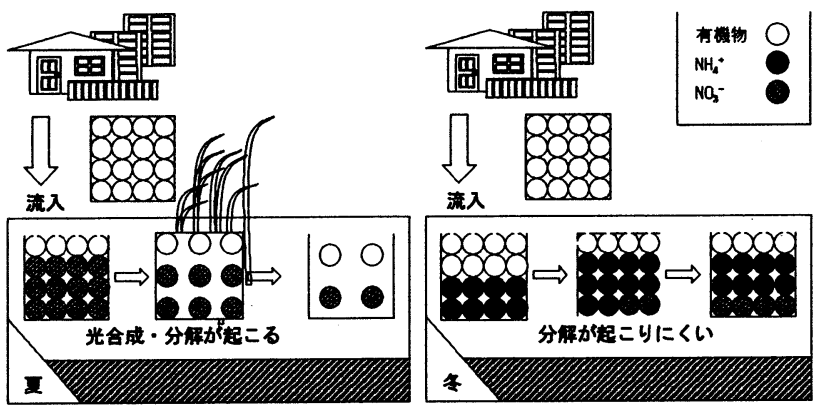

図-15 夏と冬の流域での現象の概略

なっている，特に， $25^{\circ} \mathrm{C}$ ผ上では， D0 は，飽和曲線より も上にある. したがって, $25^{\circ} \mathrm{C}$ 以上では, 光合成によっ て, 酸素が供給されたことが考えられる. さらに, 図-14 にクロロフィル $\mathrm{a}$ 濃度の変化を示す. 光合成に含まれる 物質としてクロロフィル a がある ${ }^{9}$. クロロフィル a 濃 度も夏に増加し, 冬に低くなる傾向があり, 光合成の活 動が季節変化を示しており, 夏により多くの硝酸イオン が消費されることがわかる.

\section{8. まとめ}

大和川における長期データを用いた広範囲の流域につ いての水質についての研究を行った. 大和川流域の代表 地点である藤井の $\mathrm{BOD}$, アンモニア態窒素濃度, 陰イオ ン界面活性剂濃度の時系列変化は， 2 月をピークに冬に 濃度が増加し，他の時期は低下寸る傾向が流域全体にみ られた. しかし，塩素イオンや硝酸態窒素濃度にはその ような季節変化のような規則的な変化が認められなかつ た. 濃度と流量, 水温との関係により, BOD, アンモニア 態窒素濃度は水温変化に依存し, 塩素イオン濃度は流量 に依存するとわかった. また, 硝酸態窒素濃度は流量, 水温ともに依存しないことが分かった. 河川水の濃度変 化に影響するものとして, 流量（雨水による流量増加と 希釈効果), 水温 (生物による活性) が考えられる.

平面分布により上流から下流の変化を見ると, $\mathrm{BOD} / \mathrm{Cl}^{-}$ 比, $\mathrm{NH}_{4}^{+}-\mathrm{N} / \mathrm{Cl}^{-}$比, $\mathrm{NO}_{3}^{-}-\mathrm{N} / \mathrm{Cl}^{-}$比は減少する傾向が見られ た. しかし，有機物の分解によって，最終的に硝酸イオ ンになるので, $\mathrm{BOD} / \mathrm{Cl}^{-}$比, $\mathrm{NH}_{4}{ }^{+} \mathrm{N} / \mathrm{Cl}^{-}$比が減少すれば, $\mathrm{NO}_{3}{ }^{-} \mathrm{-} / \mathrm{Cl}^{-}$比は増加するはずである. 有機物の分解と同様 に, 河川内で硝酸イオン濃度に影響を与える現象として, 光合成が考えられた. そこで, $\mathrm{pH}$ と水温, DO (溶存酸素 濃度）の関係に着目した. 光合成が起こると, 硝酸が消 費され $\mathrm{pH}$ は上昇し，酸素が発生するので，D0 は大きく なる. 大和川の河川水は $25^{\circ} \mathrm{C}$ 以上で， DO は飽和濃度よ りも高く, pH8 以上を示した. このことから, 夏に硝酸 イオンは光合成により減少することがわかる.これらの 結果から, 夏と冬の河川中で起こっている現象を図-15 に流域での現象の概略を示すように，夏には温度が高く 生物活性が高いため, 有機物分解, 硝化が速く反応し,
BOD, アンモニア濃度は低くなる. また, 硝酸イオンは光 合成により消費され, 河川水中の濃度は减少する. しか し, 冬には有機物分解, 硝化が遅く, 光合成反応があま り活発に起こらないため, 河川水中での BOD, アンモニア, 硝酸イオン濃度が低くならないと考えられた.

したがって，有機物濃度が高い排水が流入しても，夏 には深刻な問題とならないが，冬には河川の自浄能力が 低く，水質悪化を引き起こす。 このため, 冬には河川が 污染されないような十分な水質を満たした上で，河川に 排水しなければ, 水質が改善されないと考えられる. 特 に冬にアンモニア態窒素濃度が検出された奈良県の流域 南部で浄化施設などの対策をすることにより，水質改善 の効果が大きいと考えられる.

\section{参考文献}

1）大和川清流ルネッサンス 21 協議会 : 水環境改善緊急行動 計画 大和川清流ルネッサンス 21.

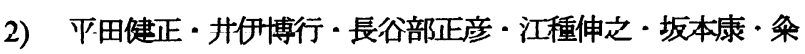
川高徳・西山幸治・酒井信行 - 岩崎䆖和 : 土地利用特性の 河川水質に及ぼす影響一大阪府石川流域一，土木学会論文 集, No.614/II -46, pp. 97-107, 1999.

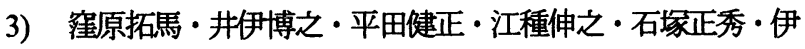
勢達男・宮川勇二 : 大和川における河川水の水質特性につ いて, 水工学論文集 45 巻, pp. 985-900, 2001.

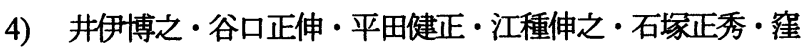
原拓馬・伊勢達男・宮川勇二 : 大和川のBOD, アンモニア 態窒素, 陰イオン界面活性剂濃度の季節变動とその原因に ふいて, 水工学論文集 46 巻, pp. 235-240, 2002.

5) 大和川工事事務所 : http/www.yamato.moc.go.jp/

6）水質水文データベース: http//wwwl.river.go.jp/

7) 有田正光 - 池田裕一 - 中井正則 - 中村由行 - 道奥康治 - 村 上和男 : 水圈の環境, 東京電機大学出版局, $\mathrm{p} 41-42,1998$

8）宗宮功·津野洋:水環境基礎科学, コロナ社 p106-109, 1998.

9）武田育郎:水質と水質環境の基礎，オーム社出版局, p56-57, 2001.

(2003.10.1 受付) 